\title{
PSYCHE
}

VoL. 56

December, 1949

No. 4

\section{NEW SPECIES OF MECOPTERA FROM NORTHWEST CHINA ${ }^{1}$}

\section{By Fung Ying Cheng \\ Taiwan Agricultural Research Institute}

The Mecoptera or scorpion flies described in the present paper were mostly collected by Prof. Io Chou, Mr. Tien Ho Hei and the writer in Sikang Province during the course of an insect pest survey for the scientific expedition of the Sino-British Committee in 1939. Other specimens were sent to me by Prof. Io Chou, Mr. Chuan Lung Lee and Mr. Chia Chu Tao, to whom I am deeply indebted. In this paper, seventeen new species are described, including one previously identified by Dr. Tjeder as cornigera.

In describing the new species, I have followed the terminology of R. E. Snodgrass in his "Principles of Insect Morphology" (1935) and F. M. Carpenter in his "Revision of the Nearctic Mecoptera" (Bull. Mus. Comp. Zool. 1931, 72 : 205-277), viz., coxopodites ("basistyles"), harpagones ("dististyles"), hypandrium ("lower appendage"), hypovalvæ (branch of hypandrium), preëpiproct ("upper appendage or epiandrium"), parameres ("ventral valves or tittilators") and rdeagus ("dorsal valves") for the males, and subgenital plate and internal skeleton for the females.

\footnotetext{
1 Contribution from the Department of Economic Zoology, Taiwan Agricultural Research Institute, published with the approval of the Director of the Institute and with a grant from the Museum of Comparative Zoology at Harvard College.
} 
I wish to express my sincere thanks to Prof. S. F. Chiu of National Peking University and Prof. S. Issiki of National Taiwan University for their encouragement during the course of my study; and to Prof. F. M. Carpenter of Harvard University for his kindness in reading over this paper.

\section{Family Panorpide}

Genus Panorpa Linn.

This genus is represented in China (not including Formosa) by 17 species, which may be grouped into three categories on the structure of the 6th abdominal segment of the male, as shown by Carpenter. In the first or centralis group, with a single anal horn, we have centralis Tjeder and flavipennis Carpenter; in the second or diceras group, with the double anal horn, we have diceras McLachlan, tjederi Carpenter, stotzneri Esben-Petersen and kimminsi Carpenter ; in the third or davidi group, without the anal horn, we have a great number of species, i.e., davidi Navas, stigmalis Navas, cladocerca Navas, tetrazonia Navas, waongkehzeni Navas, tincta Navas, japonica Thunberg, curva Carpenter and difficilis Carpenter. Two other species, guttata Navas and bonis Cheng are known only from the female, so that the position of these two species in the above grouping has yet to be determined.

\section{Panorpa emarginata $n$. sp.}

Figures 1, 11, 12, 24, 26, 29

Vertex entirely black; rostrum grayish brown anteriorly, yellowish brown laterally; thorax yellowish brown laterally, pronotum blackish brown, meso- and metanotum entirely pitchy black; the 1 st to 6 th abdominal segments pitchy black dorsally and ventrally, last few abdominal segments yellowish brown; 6th abdominal segment of male with a single anal horn, yellowish brown in color. Fore wing : length, $14 \mathrm{~mm}$.; width, $3.5 \mathrm{~mm}$.; membrane hyaline, without markings except for a slight suspicion of gray at the apex; pterostigma prominent, indi- 
cated by light brown color; the distal hind margin of wings slightly emarginated. Hind wing: length, 12.5 $\mathrm{mm}$. ; width, $3.5 \mathrm{~mm}$.; similar to fore wings. $\sigma^{\lambda}$ genitalia : genital bulb less rounded; coxopodites long, broadened towards its apex; harpagones short, the outer margin very slightly concave at the middle the inner margin with a median small triangular tooth and a large basal concave area; hypandrium inconspicuous; hypovalvæ long, with slightly concave median outer margins, extending nearly to the base of the harpagones; parameres simple and long, usually reaching to the distal part of harpagones, each consisting of a single stalk, which broadens at the middle, and each very long and sharp distally, bearing a series of long barbs at its distal inner margin; preëpiproct narrow towards the apex, with nearly straight sides and a narrow U-shaped distal incision; ædeagus with very long apical processes and well prolonged lateral processes, the distal inner margin of the former usually jointed with a broad triangular plate. $q$ genitalia: subgenital plate elongated, emarginated posteriorly, the incision being very small; internal skeleton large, the plate concave at its median sides with a pair of sharp distal posterior arms and two pairs of small basal side plates, the axis straight, extending beyond the plate nearly one-fourth its length.

Holotype (ठ) : Mt. Hwa, Shensi ; June, 1942; Io Chou; in the Museum of Comparative Zoology. Allotype (q): Same collecting data as holotype; in my own collection. Paratypes: 3 ơ 4 o, same collecting data as holotype; in National Northwest College of Agriculture, Wukung, Shensi.

This species, possessing a single anal horn, belongs to the centralis-group, with the wing membrane transparent as in centralis Tjeder. The wing apex of centralis Tjeder is colorless, whereas that of emarginata is maculated with a slight suspicion of gray. The male genitalia differ from those of centralis Tjeder by the less rounded genital bulb and the longer and sharper parameres. 
[Dee.

\section{Panorpa obtusa n. sp.}

Figures 2, 25, 27, 30

Vertex entirely black; rostrum reddish brown, with weakly defined grayish stripe on each side; thorax reddish brown laterally, entirely black dorsally; the 1st to 6 th abdominal segments black dorsally and ventrally, last few abdominal segments of male reddish brown, the hind border of the third tergite of male prolonged into a small semicircular process, 6th abdominal segment furnished with a single anal horn, reddish brown in color. Fore wing: length, $14 \mathrm{~mm}$.; width, $3.55 \mathrm{~mm}$.; membrane light grayish brown, without markings except for a slight suspicion of grayish brown at the apex ; pterostigma prominent, indicated by grayish brown color; the wing apex obtuse, broader than in the preceding species. Hind wing: length, $13 \mathrm{~mm}$.; width, $3.5 \mathrm{~mm}$.; similar to fore wing. $\delta$ genitalia: genital bulb rounded, coxopodites long; harpagones short and stout, the outer margin smoothly curved, the inner margin with a greatly reduced median tooth which cannot be seen from ventral view and a large basal concave area; hypandrium inconspicuous; hypovalvæ rather straight, reaching nearly to the base of the harpagones; parameres simple and stout, usually not extending beyond the tips of coxopodites, each consisting of a single spindle-shaped stalk, formed by the outer strongly sclerotized part; the distal inner margins of parameres furnished with a series of long barbs; preëpiproct slightly narrow towards the apex, with a wide U-shaped distal incision; ædeagus with small lateral processes and a pair of long apical processes, the inner margins of the latter nearly parallel to each other.

o unknown.

Holotype ( $\left.{ }^{\star}\right)$ : Mt. Taipai, Shensi; July 14, 1943; Chuan Lung Lee; in my own collection.

This species belongs to the centralis group, having the same wing marking as the preceding species, but the body color and the structure of male genitalia, especially the short parameres, make its recognition easy. 


\section{Panorpa typicoides n. sp.}

Figures 3, 13, 14, 28, 31

Body mostly black; vertex black anteriorly, brown posteriorly; rostrum entirely brown; thorax black dorsally, yellowish brown laterally, meso- and meta-notum as a rule with a broad brown median band; 1 st to 6 th abdominal segments of male black dorsally and ventrally, last few abdominal segments reddish brown, anal horn absent; the hind border of third tergite slightly prolonged behind, and in contact with the small, sharp conical production on the median axis of the fourth tergite; abdominal segments of female entirely black. Fore wing: length, $12.5 \mathrm{~mm}$; width, $3 \mathrm{~mm}$.; membrane hyaline, markings sooty brown; pterostigmal band complete, with a broad basal branch and a separated narrow apical branch; basal band interrupted, represented by two large spots; apical band broad, with a large hyaline spot posteriorly; basal spot very small; marginal spot large, not extending beyond the vein R1; pterostigma brown, very prominent. Hind wing: length, $11.5 \mathrm{~mm}$.; width, $3.3 \mathrm{~mm}$.; similar to fore wings, except that the basal spot and the anterior part of the basal band are entirely lacking. $\delta$ genitalia: genital bulb rounded; coxopodites long, U-shaped, furnished with a series of long hairs at the distal inner portions; harpagones slender, the outer margin slightly concave at the middle, the inner margin with a median angle and a small basal concave area; hypandrium inconspicuous; hypovalvæ rather long, reaching to the base of the harpagones; parameres simple and slender, each consisting of a single stalk, which is distinctly twisted and pointed at its apex; preëpiproct slender, slightly narrow towards apex, with a deep U-shaped distal incision; ædeagus with fingershaped apical processes and slightly prolonged lateral processes, the distal inner margins of the former usually produced inwards to form a small nipple-shaped plate. genitalia: subgenital plate elongated, broadened at the middle; internal skeleton long, the plate narrow towards its base with a pair of sharp posterior arms, the axis very 
long, extending nearly two-thirds its length beyond the plate.

Holotype ( $\left.0^{\star}\right)$ : Tachienlu, 5000-8500 ft., Sikang; Aug. 27, 1939; F. Y. Cheng, Io Chou and Tein Ho Hei; in the Museum of Comparative Zoology. Allotype (q): Same collecting data as holotype, in my own collection. Paratype: $1 \delta^{\sigma}$, same collecting data as holotype, in my own collection.

This species, belonging to the davidi group, is a very interesting one, superficially resembling the common European species communis; but the peculiar shape of the genital segments both in male and female makes it easily recognized as a distinct species.

Panorpa fructa n. sp.

Figures 5, 6, 7,

Body mostly sooty black, last few abdominal segments of male reddish brown, vertex black anteriorly, deeply reddish brown posteriorly; rostrum uniformly reddish brown. Fore wing: length, $11.5 \mathrm{~mm}$. ; width, $3 \mathrm{~mm}$. ; membrane hyaline, markings light brown, ill-defined, fragmentary; pterostigmal band incomplete, with a spot-like basal branch; basal band represented by two spots ; apical band appears as a light suspicion of brown at the apex; basal spot very small; marginal spots large; pterostigma not very prominent. Hind wing: length, unknown; width, $3 \mathrm{~mm}$.; similar to fore wing, except that basal band and basal spot are entirely absent. $\sigma^{t}$ genitalia: genital bulb very rounded; coxopodites long, stout, with four spinelike hairs and a series of short hairs in its distal inner portions; harpagones slender, the outer margin rather straight, the inner margin with a median angle and a rather large basal concave area; hypandrium inconspicuous; hypovalvæ shorter than in the preceding species, far from reaching to the base of the harpagones; parameres simple, long and twisted, the distal half well-developed, with rounded apex furnished with a short spine-like tip; preëpiproct rather short, broad at the base, narrow towards apex, with a broad U-shaped distal incision; 
ædeagus with long apical processes and long lateral processes, the former with rather straight inner margins and double sinuous outer margins.

o unknown.

Holotype ( $\left.\delta^{\wedge}\right)$ : Wakiakeng, 50 miles west of Tachienlu, Sikang; Sept. 9, 1939 ; F. Y. Cheng, Io Chou and Tein Ho Hei ; in my own collection.

This species belongs to the davidi group, and resembles that species superficially, but differs in the broader genital bulb and especially in the well-developed distal part of the parameres and in the shape of the ædeagus.

Panorpa sexspinosa n. sp.

Figures 4, 8, 9, 15, 16

Vertex yellowish brown, with four dark spots on its anterior region, one small spot enclosing the median ocelli anteriorly, one around the other two ocelli posteriorly, the other two are on both sides of the former two spots; rostrum uniformly yellowish brown; thorax blackish brown dorsally, light yellow laterally, meso- and meta-notum as a rule with broad median light yellowish streaks; abdominal segments dark brown dorsally, light brown ventrally, hind part of 6th abdominal segment of male and its last few abdominal segments yellowish brown, the hind border of the third tergite with a bandlike prolongation. Fore wing: length, $12 \mathrm{~mm}$.; width, 3 mm.; membrane hyaline, markings darkish brown ; pterostigmal band complete, with a broad basal branch and a narrow apical branch; basal band unusually broad; apical band complete, with a hyaline spot; basal spot very small; pterostigma not very prominent. Hind wing: length, 10.8 mm.; width, $3 \mathrm{~mm}$.; similar to fore wing, except that the small basal spot is lacking. $\sigma^{\lambda}$ genitalia: genital bulb rounded; coxopodites long, with six spines on its distal inner margins; harpagones slender, the outer margin smoothly curved, the inner margin with a reduced median angle and a large basal concave area ; hypandrium inconspicuous; hypovalvæ rather short, not nearly reaching to the base of the harpagones; parameres narrow and 
slender, each consisting of a single stalk which is somewhat twisted and pointed at its tip; preëpiproct slender, the distal incision being almost quadrate; apical processes of ædeagus somewhat prolonged on its distal outer margins, lateral processes well-developed. $q$ genitalia: subgenital plate elongated, slightly emarginate posteriorly; internal skeleton large, the plate distinctly concave at its base, with a pair of sharp posterior arms and a pair of anterior side plates; axis well-developed, extending beyond the plate for nearly one-third its length.

Holotype ( $\left.0^{\star}\right)$ : Mt. Taipai, Shensi, June, 1942; Io Chou; in my own collection. Allotype ( $q$ ): Same collecting data as holotype; in the Museum of Comparative Zoology. Paratype: 1 , same collecting data as holotype; in my own collection.

This species, belonging to the davidi group, differs from the others in its wing markings; the basal band is as broad as in cladocerca Navas, but its pterostigmal band is quite different. The structure of male genitalia, especially the six spines on the distal coxopodites, makes its recognition easy.

\section{Panorpa semifasciata $\mathrm{n}$. sp.}

Figures 19, 20, 21, 53

Body entirely sooty black; vertex black; rostrum uniformly black; the middle part of 8th abdominal tergite slightly prolonged into a band-like prolongation, the 9th abdominal tergite very broad, its lateral borders bent ventrad to embrace the posterior part of subgenital plate in ventral view. Fore wing: length, $14 \mathrm{~mm}$; width, 3.5 mm.; membrane light yellow, markings sooty brown; pterostigmal band incomplete, with an interrupted narrow basal branch; apical band small, with two hyaline spots ; pterostigma prominent. Hind wing: length, 12.8 $\mathrm{mm}$.; width, $3 \mathrm{~mm}$; ; similar to fore wing, except that the basal branch of pterostigmal band is greatly reduced. $q$ genitalia: subgenital plate broad, with strongly sclerotized median part and less sclerotized lateral borders, apex of subgenital plate rounded, less sclerotized, fur- 
nished with several long hairs ; internal skeleton flattened, the plate very small, less sclerotized, the posterior arms of the internal skeleton very long, sharp and strongly sclerotized, axis flattened, jointed with posterior arms and extending a little beyond the plate.

ot unknown.

Holotype (ㅇ) : Jihti, 30 miles east of Tachienlu, Sikang; Sept. 1, 1939 ; F. Y. Cheng, Io Chou and Tein Ho Hei ; in my own collection.

This species differs from all the formerly described species by its body color, reduced wing markings and the peculiar shape of the genital segment of female. The position of this species in the above grouping is not determined.

\section{Panorpa leei n. sp. \\ Figures 17, 18, 54}

Vertex black; rostrum reddish brown, with a short and deep brown stripe on each side of its upper portion; thorax black dorsally, yellowish brown laterally; 1st to 6 th abdominal segments black dorsally and ventrally, the 7 th to 9 th abdominal segments very small, reddish brown. Fore wing : length, $14 \mathrm{~mm}$.; width, $4 \mathrm{~mm}$.; membrane hyaline, markings sooty brown; pterostigmal band broad, with a complete basal branch, and a greatly reduced spotshaped apical branch; apical band small, including a prominent narrow band and some faintly smoky spots; pterostigma prominent. Hind wing: length, $13 \mathrm{~mm}$; width, $3.55 \mathrm{~mm}$.; similar to fore wing, except that the basal branch of pterostigmal band is greatly reduced. $q$ genitalia : subgenital plate small, narrowed posteriorly, apex rounded; internal skeleton long, the plate abruptly narrow at the base, with a pair of sharp posterior arms, the axis extending for nearly half its length beyond the plate.

$o^{\lambda}$ unknown.

Holotype () : Mt. Taipai, Shensi ; July 14, 1943 ; Chuan Lung Lee; in the Museum of Comparative Zoology. Para- 
type: 1 o same collecting data as holotype; in my own collection.

The material was collected by Chuan Lung Lee, in honour of whom I name the species.

This species differs from all the formerly described species by its wing markings and the peculiar shape of the genital segment of the female. The position of this species in the above grouping is not determined.

Panorpa statura $\mathrm{n}$. $\mathrm{sp}$.

Figures 32, 33, .34, 57

Vertex dark brown anteriorly, with a black mark within the ocelli, light brown posteriorly, with a median and a pair of longitudinal bands; rostrum uniformly reddish brown; thorax entirely brown laterally, prothorax dark brown dorsally, meso- and meta-notum uniformly blackish brown; the 1st to 4th abdominal segments of the female blackish brown dorsally; brown ventrally, last few abdominal segments entirely brown. Fore wing : length, $16.5 \mathrm{~mm}$.; width, $4.55 \mathrm{~mm}$.; membrane yellowish brown, markings deep brown; pterostigmal band complete, with a broad basal branch and a broad apical branch; basal band interrupted; apical band large with a hyaline spot; marginal spot very small; pterostigma not very prominent. Hind wing: length, $15 \mathrm{~mm}$.; width, $4.2 \mathrm{~mm}$.; similar to fore wing, except that the small marginal spot is lacking. $q$ genitalia: subgenital plate elongated, narrowed posteriorly, shallowly emarginated at its apex, its lateral borders bent laterad to form a narrow lateral portion; internal skeleton long, the plate concave on its median sides with a pair of short tooth-like posterior arms, the axis long, extending beyond the plate for exactly half its length.

ot unknown.

Holotype (ㅇ) : Mt. Taipai, Shensi ; July 14, 1943 ; Chuan Lung Lee, in my own collection.

This species, having a yellowish brown wing membrane, differs from flavipennis Carpenter by its very long wing and the markings of the apical band. The peculiar shape 
of the genital segment of the female enables its easy recognition. The position of this species in the above grouping is not determined.

\section{Panorpa pusilla n. sp.}

Figures 37, 38, 52

Vertex yellow anteriorly with a black spot enclosing ocelli, sooty brown posteriorly with a median quadrangular plate; rostrum uniformly yellow; thorax brownish yellow dorsally, yellow laterally, meso- and meta-notum with sooty brown markings on each side; abdominal segments sooty brown dorsally, yellow laterally and ventrally. Fore wing: length, $1.8 \mathrm{~mm}$; width, $0.28 \mathrm{~mm}$.; membrane yellow, markings sooty brown; pterostigmal band complete, with a complete basal branch and a separated apical branch; basal band complete; apical band represented by two prominent bands, the inner one narrow, being parallel to the pterostigmal band, the outer one including the wing apex; basal spot situated on the hind margin of wing; marginal spot very large; pterostigma not very prominent. Hind wing : length, $0.95 \mathrm{~mm}$.; width, $0.28 \mathrm{~mm}$; ; similar to fore wing, except that the basal spot on the hind margin of wing is entirely lacking. o genitalia : subgenital plate elliptical, with a slightly distal emargination; the plate of internal skeleton small, the posterior arms of the plate large, twisted at the middle, the axis short and slender, not extending beyond the plate.

on unknown.

Holotype (q) : Mt. Taipai, Shensi, June, 1942 ; Io Chou ; in the Museum of Comparative Zoology. Paratype: 1 , same collecting data as holotype; in my own collection.

This species, having yellowish wing membrane differs, from the other described species by its very small body size, wing markings and the peculiar shape of the genital segment of the female. The position of this species in the above grouping is not determined. 


\section{Panorpa bonis $\mathrm{n}$. sp.}

Panorpa cornigera Tjeder (nec McLachlan) Ark. Zool., Bd. 27A, no. 33, p. 7 (1935).

The female of this species, which has been well described and figured by Tjeder, resembles cornigera, but I am convinced that it is a distinct species. This is also the opinion of Dr. Issiki, who has collected many individuals of the true cornigera in Korea and East Siberia. I am, therefore, describing here as new the species identified as cornigera by Tjeder.

The "additional side plates" of 7th-8th abdominal segments of this species are not so slender as those of cornigera. The subgenital plate is pointed at its posterior part, and shallowly emarginate at its apex, while that of cornigera is rounded and not emarginate. The internal skeleton of this species is quite distinct from that of cornigera: the plate of the former is slender with a small proximal part and short blunt posterior arms; while that of the latter is broad, with a well-developed oval proximal part and long pointed posterior arms. The axis of this species extending beyond the plate is less than half the length of the whole axis, while that of cornigera usually extends beyond the plate more than half its length.

ot unknown.

Holotype () : Lupasze, at River Tao Ho, South Kansu, about $2.750 \mathrm{~m}$; July 11, 1930; Dr. D. Hummel; in the Stockholm Museum.

The position of this species in the above grouping is not determined.

\section{Genus Neopanorpa Weele}

This genus has heretofore been represented in China (not including Formosa) by ten species, of which apicata, caveleriei, dimidiata, lacunaris, pielina and brisi were described by Navas; and claripennis, nigritis, chelata and banksi by Carpenter.

In this paper six species are described as new, of which validipennis and tao $i$ have undeveloped parameres, 
and choui bears a large internal skeleton with a well-developed axis.

Neopanorpa choui n. sp.

Figures 22, 23, 43, 44, 45, 62

Body light brown, the middle part of the thoracic notum sooty brown; vertex entirely black; rostrum yellowish brown; median process of third abdominal tergite of male extraordinarily long (measuring up to $4.2 \mathrm{~mm}$.) apparently divided into two portions and bearing a series of dense, short stiff hairs on its ventral surface; the fourth tergite extremely long, almost covering the following abdominal segments, somewhat elevated, and furnished with many short stiff hairs on its surface. Fore wing: length, $3.5 \mathrm{~mm}$.; width, $3 \mathrm{~mm}$.; membrane light yellowish brown, markings light brown, very indistinct; pterostigmal band incomplete, usually represented only by the faint basal branch and apical branch; basal band represented only by two small spots on the hind margin; apical band large; pterostigma brown, very prominent. Hind wing : length, $12 \mathrm{~mm}$.; width, $3 \mathrm{~mm}$.; similar to fore wing, except that the pterostigmal band and the basal are entirely lacking. $\delta$ genitalia: genital bulb slender; coxopodite long, with truncated apex; harpagones slender, the outer margin concave at the middle, inner margin with a triangular angle and a large basal lobe; hypandrium short and broad; hypovalvæ broad and less sclerotized, with an abruptly narrow apex, extending beyond the base of the harpagones; parameres modified into a pair of sclerotized rods, greatly swollen distally and with an incised apex and fused with the basal part of æedeagus basally; preëpiproct narrow distally with truncated and slightly concave apex. ÆEdeagus rather small, the two apical processes united together; lateral process extending upward with tooth-like apex. $q$ genitalia: subgenital plate broad basally, narrow towards apex and with a narrow U-shaped incision distally; internal skeleton large, the plate little sclerotized, very small, its posterior arms 
narrow and slender, sword-shaped, the axis very stout with abruptly curved hook-shaped basal ends.

Holotype (o ) : Mt. Chowkung, Yaan, Sikang; July 14, 1939 ; F. Y. Cheng, Io Chou and Tein Ho Hei ; in my own collection. Allotype () : Same collecting data as holotype; in my own collection. Paratypes: 19 , same collecting data as holotype ; in the Museum of Comparative Zoology ; 2 \&, same collecting data as holotype; in my own collection.

I take the liberty of naming this species in honour of Prof. Io Chou, of the National Northwest College of Agriculture, who was so kind to me during our expedition.

This species differs from other described Neopanorpa by its very long median process of the third abdominal segment and the peculiar structures of both male and female genitalia.

\section{Neopanorpa heii n. sp.}

Figures 35, 36, 49, 50, 51

Vertex entirely black; rostrum uniformly brown; thorax sooty brown dorsally, deep brown laterally; the 1st to 5th abdominal segments of male sooty brown dorsally, deep brown laterally and ventrally, 6 th abdominal segment twice the length of 5th segment, sooty brown in color, last three abdominal segments also very long, deep brown in color; median process of the third tergite short, never extending to the middle of the fourth tergite, and in contact with the conical projection on the median axis of the fourth tergite; abdominal segments of female sooty brown dorsally, deep brown laterally and ventrally. Fore wing: length, ô $12.8 \mathrm{~mm}$.; $ᄋ 13.5 \mathrm{~mm}$.; width, $\sigma^{\lambda} 3.2$ mm.; $93 \mathrm{~mm}$.; membrane slightly brown, markings sooty brown; pterostigmal band complete, with a broad basal branch and a greatly reduced and separated apical branch; basal band represented by a reduced marking on the hind margin; apical band well-developed; basal spot very small; marginal spot consisting of two reduced spots; pterostigma prominent. Hind wing: length, $\sigma^{\star}$ $11.5 \mathrm{~mm}$.; 우 $12.2 \mathrm{~mm}$.; width, of $3.2 \mathrm{~mm}$.; o $3 \mathrm{~mm}$.; simi- 
lar to fore wing, except that apical branch of pterostigmal band, basal band, basal spot and marginal spot are entirely lacking. $\delta$ genitalia : genital bulb slender; coxopodites rather long, with a projecting apex; harpagones very slender, the outer margin slightly concave at the middle, inner margin with a smooth angle and a true basal lobe; hypandrium rather long; hypovalvæ not flattened, broadened towards the apex, the basal portion wide apart, the median inner parts greatly prolonged upward and overlapping each other; parameres apparently absent; preëpiproct slightly narrow towards the apex, the distal portion bent laterad and caudad so as to embrace the proctiger; ædeagus very small, both the apical and the lateral processes tooth-like, the basal part usually covered by a pair of elliptical membranous plates. q genitalia : subgenital plate broad, with a wide U-shaped distal incision; internal skeleton small, the plate being band-shaped, transversely elongated, the posterior arms of the internal skeleton lanceolate, extending laterad and reaching to the side margins of the subgenital plate, the axis small, fork-shaped, the distal portions of the forks jointed with the basal posterior arms closely.

Holotype (ठ) : Mt. Chowkung, Yaan, Sikang; July 29, 1939, F. Y. Cheng, Io Chou and Tein Ho Hei; in my own collection. Allotype (q) : Same collecting data as holotype, in my own collection.

I take the liberty of naming this species in honour of Mr. Tein Ho Hei, who was so kind to me during our expedition.

This species superficially resembles caveleriei Navas in wing markings, but it can be distinguished by the greatly reduced apical branch of the pterostigmal band in the fore wing and the entire lack of this band in the hind wing. Another difference is the unforked R2a of this species as compared with the forked R2a in the redescribed figure of caveleriei Navas by Esben-Petersen (1921, p. 83). However, the specific characteristics eannot be determined for certain until the structure of the 9th abdominal segment has been studied. This species 
also resembles chelata Carp. in wing markings but these two species are at once distinguished by the forms of both male and female genitalia.

\section{Neopanorpa validipennis $\mathrm{n}$. sp.}

Figures 46, 47, 48, 64, 65

Vertex entirely black; rostrum deep brown, with a median longitudinal light brown streak; thorax sooty brown dorsally, brown laterally, the 1st to 5th abdominal segments of male dark brown dorsally, reddish brown ventrally, 6th segment long, sooty brown, 7th segment reddish brown, 8th segment reddish brown anteriorly, sooty brown posteriorly, both the 7th and 8th segments broaden towards apex, the posterior end of the pleural regions of 7 th segment protruding posteriorly to form two small processes, median process of the third tergite rather long, extending nearly to the hind border of the fourth tergite, pointed at the apex when seen dorsally. Under this median process, there is another reddish small process, and on both sides of this median process is a pair of small tooth-like prolongations, the median axis of the fourth tergite slightly protruding upward. Fore wing: length, $14.5 \mathrm{~mm}$.; width, $3.5 \mathrm{~mm}$.; membrane grayish brown, no markings present; veins very stout, R2a usually forked into R2a1 and R2a2; pterostigma not very prominent. Hind wing: length, $13.5 \mathrm{~mm}$.; width, $3.5 \mathrm{~mm}$.; similar to fore wing. $\delta^{\lambda}$ genitalia : genital bulb slender; coxopodites very long, abruptly narrow distally, bearing a number of long hairs on the distal inner margins; harpagones short and slender, the outer margin slightly concave at the middle, furnished with a series of short barbs at the basal half, inner margin with a large lobe basally; hypandrium long, slightly narrow towards apex; hypovalvæ with slender basal stalks, wide apart basally, overlapping each other, the outer borders extending laterad and concave near its middle; parameres club-shaped with rounded apex; preëpiproct slender with rounded apex, the distal outer portion extended laterad to embrace the proctiger, and forming distal tooth-like 
processes; ædeagus very small, the two apical processes nearly united, lateral processes extended posteriorly, sharp and tooth-like.

o unknown.

Holotype ( $\left.\delta^{\top}\right)$ : Jihti, 30 miles east of Tachienlu, Sikang; Sept. 2, 1939; F. Y. Cheng, Io Chou and Tein Ho $\mathrm{Hei}$; in my own collection.

This species resembles claripennis Carp. and nigritis Carp. in lacking color markings of wings, but the form of the male genitalia makes its recognition easy.

Neopanorpa taoi n. sp.

Figures 10, 58, 66, 68

Body light brown; vertex entirely black; rostrum light brown with sooty brown stripe on each side; pronotum sooty brown, meso- and meta-notum sooty brown on the median portion; the 1st to 5th abdominal segments of male sooty brown dorsally, last few abdominal segments brown in color, median process of third abdominal tergite short with swollen and truncated apex, not extending beyond the middle of the fourth tergite. Under this process, there is a small median process and a pair of lateral processes; the fourth tergite is provided with a concave area on its anterior portion. Fore wing: length, $0.7 \mathrm{~mm}$. ; width, $3.8 \mathrm{~mm}$. ; membrane light gray, no markings present, R2a usually forked into R2a1 and R2a2 ; pterostigma prominent. Hind wing: length, $15.8 \mathrm{~mm}$.; width, $3.8 \mathrm{~mm}$.; similar to fore wing. $\sigma^{\Uparrow}$ genitalia: genital bulb slender; coxopodites long, narrow distally, bearing many long hairs; harpagones rather short, the outer margin convex basally, furnished with a series of short barbs at the middle, inner margin with a large basal lobe with two tooth-like processes, hypandrium broad, hypovalvæ wide apart basally, slightly overlapping each other distally, the basal outer margins greatly convex and strongly sclerotized, parameres simple, lanceolate; preëpiproct slender, with median concaved margins, the distal outer portions extended laterad, forming large, distal, toothlike processes; ædeagus rather small, both apical proc- 
[Dec.

esses and lateral processes tooth-like, extending the same direction and having nearly the same size.

o unknown.

Holotype (ठ): Mt. Lo, Sichang; June 10, 1944, Chia Chu Tao; in my own collection.

The species is named in honour of Chia Chu Tao. It differs from the preceding one by the broadened apex of the median process of the 3rd abdominal segment and also by the structure of the male genitalia.

Neopanorpa latipennis n. sp.

Figures 39, 40, 55

Body deep brown, black above, vertex black anteriorly, brown posteriorly, with a sooty brown marking on the median portion; rostrum brown, with a sooty brown median stripe on its lower portion. Fore wing: length, $14 \mathrm{~mm}$; width, $3.53 \mathrm{~mm}$.; membrane hyaline, markings sooty brown; pterostigmal band very broad, with broad basal branch and narrow apical branch, basal band not very prominent, extending to the median portion of the fore wing, apical band very large, represented by a big marking and an inner small $\mathrm{Y}$-shaped band; marginal spots small; pterostigma prominent; the wing apex rather broad. Hind wing: length, $12.55 \mathrm{~mm}$.; width, 3.5 $\mathrm{mm}$.; similar to fore wing, except that the apical branch of pterostigmal band, the inner small Y-shaped band of apical band and the basal band are greatly reduced. $q$ genitalia: subgenital plate abruptly narrow posteriorly, with a wide U-shaped distal incision; internal skeleton small, being U-shaped, with a small stalk at its base, the axis apparently absent.

$\sigma^{\pi}$ unknown.

Holotype () : Moupin, Sikang; July 29, 1941; Chuan Lung Lee : in my own collection.

This species differs from described Neopanorpa by its additional small Y-shaped band between the pterostigmal and apical bands in the fore wings. The stalk bearing U-shaped internal skeleton of the female enables its easy recognition. 
Neopanorpa varia $\mathrm{n}$. sp.

Figures 41, 42, 56

Body light brown, black above, last few abdominal segments brown, vertex entirely black; rostrum light brown with black stripe on each side. Fore wing: length, 14 mm.; width, $3.2 \mathrm{~mm}$; ; membrane slightly brown, markings sooty brown; pterostigmal band complete, with a separated basal branch and a narrow apical branch; apical band complete; pterostigma prominent. Hind wing: length, $13 \mathrm{~mm}$.; width, $3.3 \mathrm{~mm}$.; similar to fore wing, except that the basal band is represented by a small marking on the hind margin. o genitalia: subgenital plate broad, with a U-shaped distal incision; internal skeleton large, U-shaped, posterior arms rather long, obtuse distally, very large basally, with a narrow sclerotized bridge and a rounded membranous portion between them, axis apparently absent.

o unknown.

Holotype () : Heierhwan, 100 miles south of Tachienlu, Sikang; Sept. 20, 1939; F. Y. Cheng, Io Chou and Tein Ho Hei; in my own collection. Paratypes: 1 우 Jihti, 20 miles east of Tachienlu, Sikang; Sept. 2, 1939; 1 q Tienwan, 30 miles south of Tachienlu, Sikang; Sept. 9, 1939; 1 \% Wantung, 50 miles south of Tachienlu, Sikang; Sept. 17, 1939; F. Y. Cheng, Io Chou and Tien Ho Hei; in my own collection.

This species is somewhat variable with regard to the markings of the wings; in my collection, there is one individual collected in Wantung, Sikang, with a greatly reduced pterostigmal band on both fore and hind wings and without the basal band on the hind wing.

This species resembles chelata Carp. in wing markings, but differs greatly in the structure of the female genitalia. The internal skeleton of this species resembles banksi Carp. superficially, but differs in its basal structure as compared with the three well-developed plates which appear on the base of the internal skeleton of banksi Carp. The wings of this species differ from 
those of caveleriei Navas by the absence of a transverse marking which joins the pterostigmal and apical bands at the anterior margin of the wing. The wings of this species resemble those of dimidiata Navas, but the body color differs very much. However, the specific characteristics cannot be determined with certainty until the structure of the 9th abdominal segment has been studied.

\section{Family Bittacid五}

\section{Genus Bittacus Latr.}

This genus has been represented in China (not including Formosa) by four species, of which sinensis was described by Walker, pieli by Navas, and triangularis and sinicus by Issiki.

Bittacus planus n. sp.

Figures 59, 60, 61, 63, 67

Body light brown, vertex brown, with sooty brown marking enclosing ocelli; rostrum brown; meso-thorax with two sooty brown spots on each side dorsally. Fore wing: length, $20.2 \mathrm{~mm}$.; width, $5.2 \mathrm{~mm}$.; the wing apex broad, obtuse; membrane light brown without markings, veins brown, cross veins slightly emarginated; pterostigma not very prominent, apical cross vein in the area between $\mathrm{Cu} 2$ and $1 \mathrm{~A}$ absent. Hind wing: length, 17.5 $\mathrm{mm}$.; width, $4.2 \mathrm{~mm}$.; similar to fore wing, except that there is only one cross vein between the pterostigma and R2. $\sigma^{\top}$ genitalia: preëpiproct with $V$-shaped inner margins, when seen from above, with truncated apex, the apical margins being slightly concave, furnished with a series of short black bristles on its interior sides; caudal end of coxopodites produced upward rather long with smooth apex; harpagones broad basally, very narrow and slender distally, with prominent inner process; ædeagus lobes on each side of the base of filum broaden towards apex with truncated tips; proctiger narrow towards apex, furnished with a bundle of short hairs; the lower process very long, pointed towards its apex. 
Holotype ( $\left.\delta^{\star}\right)$ : Mt. Taipai, Shensi, June, 1942 ; Io Chou; in my own collection. Paratypes: $10^{\top}, 1$, same collecting data as holotype; in the Museum of Comparative Zoology. $20^{*}, 3$, same collecting data as holotype; in National Northwest College of Agriculture, Wukung, Shensi.

This species differs from the previously described species by the peculiar shape of the preëpiproct in lateral view, the slender harpagones and the broadened apex of the ædeagus lobes. 


\section{Explanation of Plate 7}

Fig. 1. Panorpa emarginata $n$. sp., preëpiproct of $\hat{\delta}$. (Holotype).

Fig. 2. Panorpa obtusa n. sp., preëpiproct of $\hat{o}$. (Holotype).

Fig. 3. Panorpa typicoides $n$. sp., preëpiproct of $\hat{\delta}$. (Holotype).

Fig. 4. Panorpa sexspinosa $\mathrm{n}$. sp., preëpiproct of $\hat{\delta}$. (Holotype).

Fig. 5. Panorpa fructa n. sp., ventral view of $\hat{o}$ genital bulb. (Holotype).

Fig. 6. Panorpa fructa $n$. sp., preëpiproct of $\hat{o}$. (Holotype).

Fig. 7. Panorpa fructa $\mathrm{n}$. sp., ventral view of $\hat{o}$ genital bulb. (Holotype).

Fig. 8. Panorpa sexspinosa $n$. sp., ventral view of ô genital bulb. (Holotype).

Fig. 9. Panorpa sexspinosa n. sp., ventral view of $\hat{o}$ genital bulb, showing ædeagus. (Holotype).

Fig. 10. Neopanorpa taoi $\mathrm{n}$. sp., ventral view of $\hat{o}$ genital bulb. (Holo. type). 


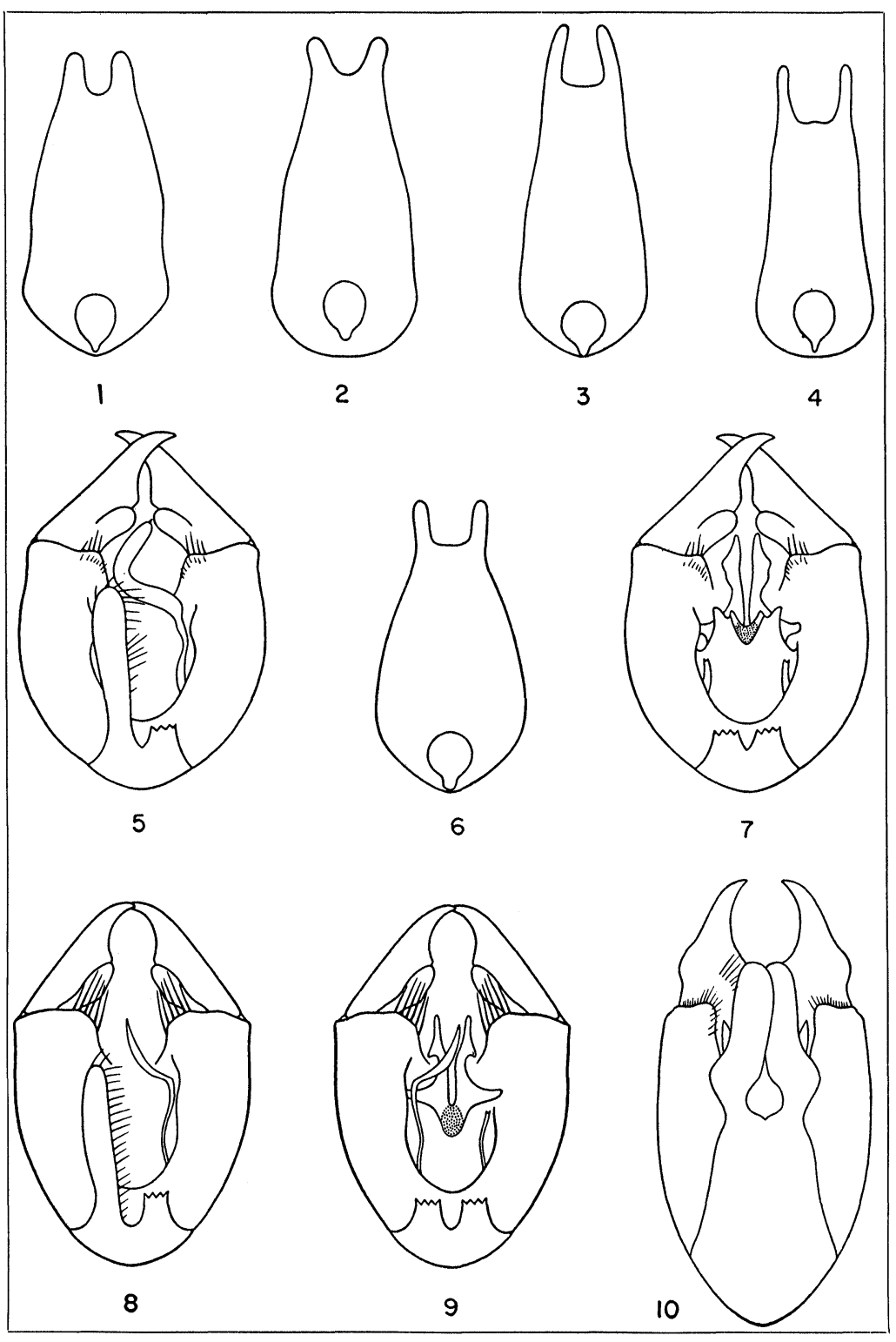

Cheng-Mecoptera 
Fig. 11. Panorpa emarginata n. sp., subgenital plate of $q$. (Allotype). Fig. 12. Panorpa emarginata n. sp., internal skeleton of + . (Allotype). Fig. 13. Panorpa typicoides n. sp., subgenital plate of ${ }^{\circ}$. (Allotype). Fig. 14. Panorpa typicoides n. sp., internal skeleton of ${ }^{\circ}$. (Allotype). Fig. 15. Panorpa sexspinosa n. sp., subgenital plate of + . (Allotype). Fig. 16. Panorpa sexspinosa n. sp., internal skeleton of ${ }^{\circ}$. (Allotype). Fig. 17. Panorpa leei n. sp., subgenital plate of ${ }^{\circ}$. (Holotype). Fig. 18. Panorpa leei n. sp., internal skeleton of + . (Holotype).

Fig. 19. Panorpa semifasciata n. sp., ventral view of $\$$ last few abdominal segments. (Holotype).

Fig. 20. Panorpa semifasciata n. sp., internal skeleton of $ᄋ$. (Holotype). Fig. 21. Panorpa semifasciata n. sp., subgenital plate of ${ }^{\circ}$. (Holotype). Fig. 22. Neopanorpa choui n. sp., subgenital plate of ${ }^{\circ}$. (Allotype). Fig. 23. Neopanorpa choui n. sp., internal skeleton of $q$. (Allotype). 


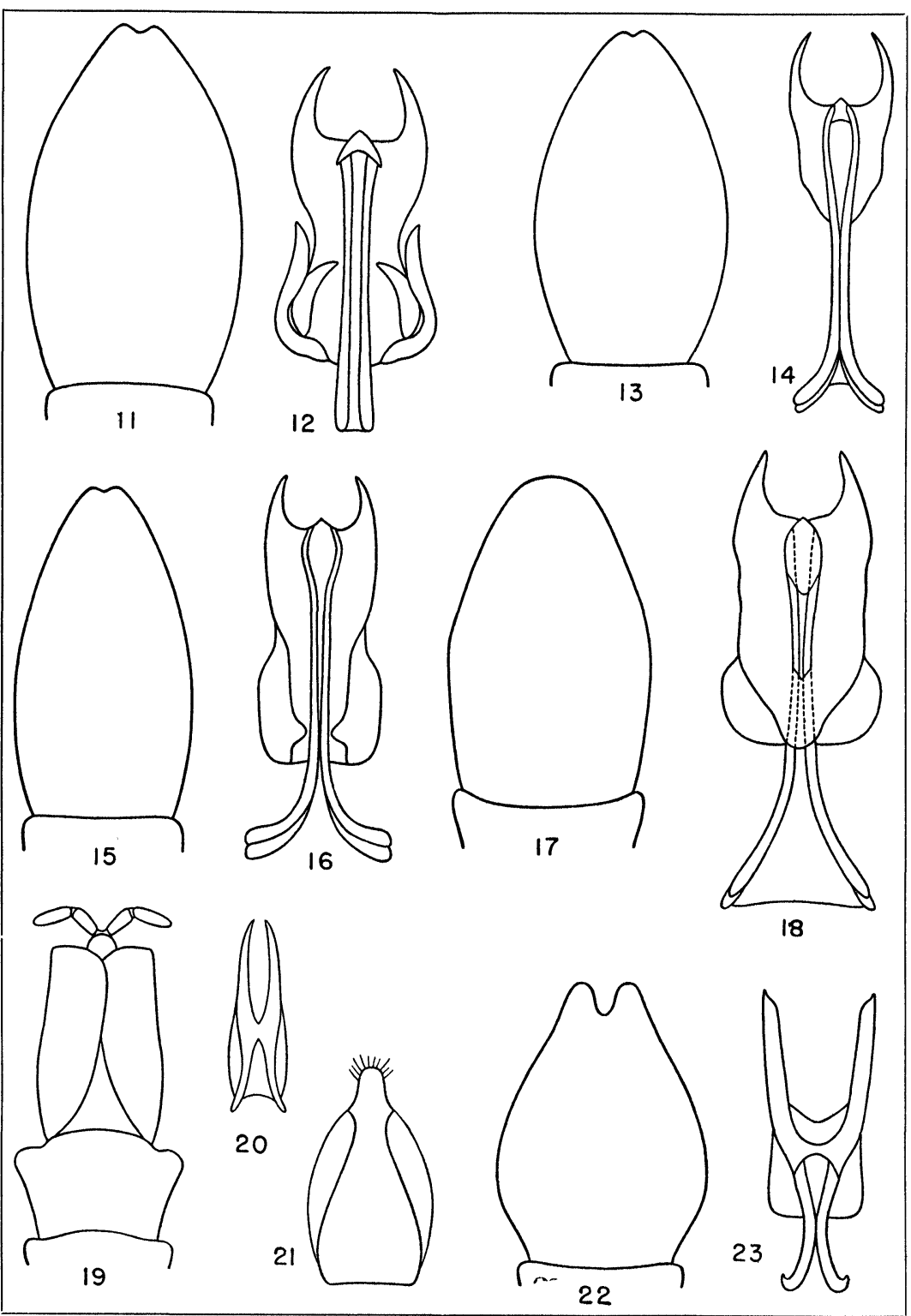

CHENG-MeCOPterA 


\section{Explanation of Plate 9}

Fig. 24. Panorpa emarginata n. sp., lateral view of $\hat{o}$ last few abdominal segments. (Holotype).

Fig. 25. Panorpa obtusa n. sp., lateral view of $\hat{o}$ last few abdominal segments. (Holotype).

Fig. 26. Panorpa emarginata n. sp., ventral view of ô genital bulb. (Holotype).

Fig. 27. Panorpa obtusa n. sp., ventral view of $\hat{\delta}$ genital bulb. (Holotype).

Fig. 28. Panorpa typicoides n. sp., ventral view of $\hat{o}$ genital bulb. (Holotype).

Fig. 29. Panorpa emarginata $n$. sp., ventral view of $\hat{o}$ genital bulb, showing ædeagus. (Holotype).

Fig. 30. Panorpa obtusa n. sp., ventral view of $\hat{\sigma}$ genital bulb, showing ædeagus. (Holotype).

Fig. 31. Panorpa typicoides n. sp., ventral view of $\hat{o}$ genital bulb, showing ædeagus. (Holotype). 


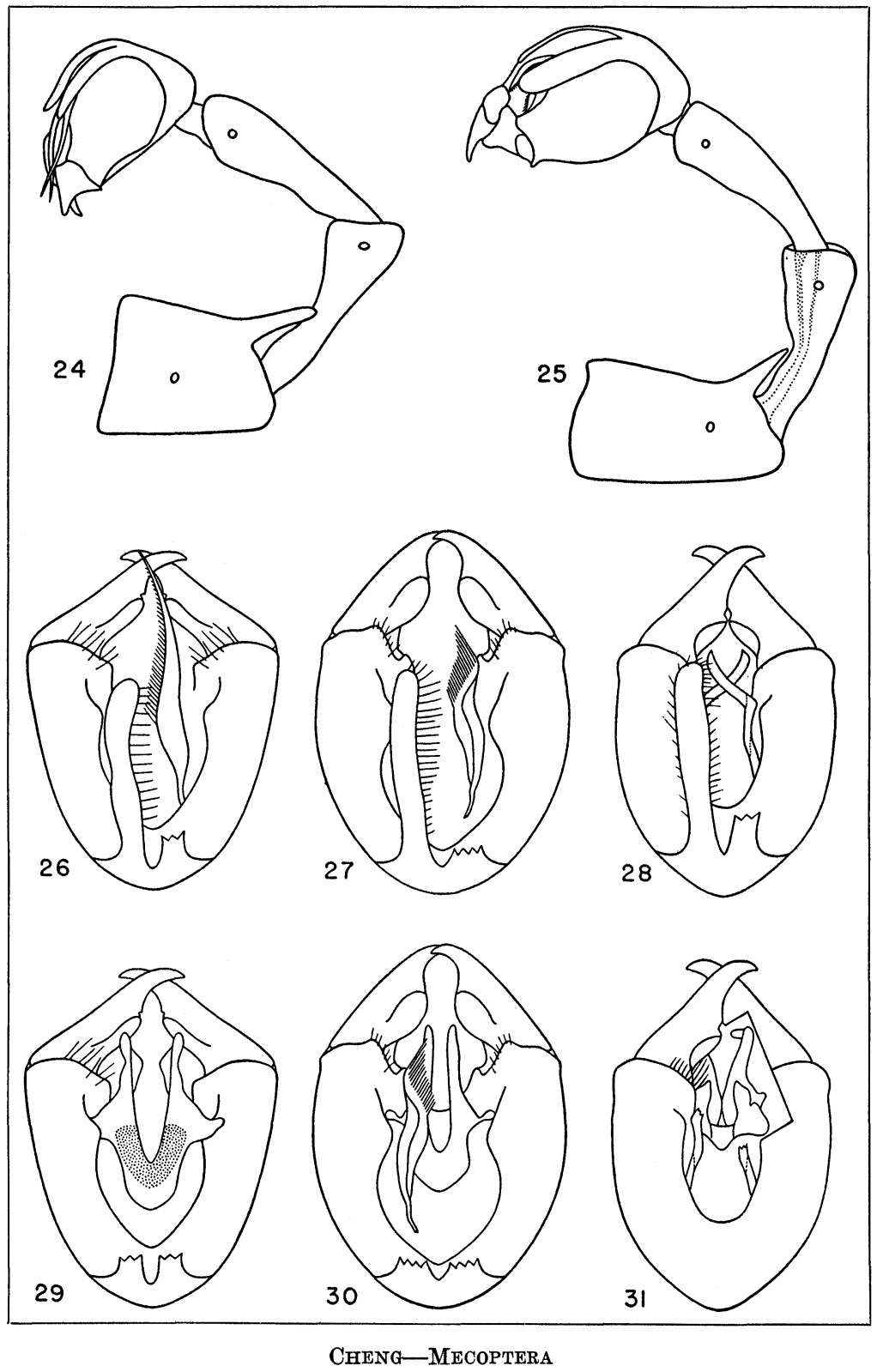




\section{Explanation of Plate 10}

Fig. 32. Panorpa statura n. sp., lateral view of subgenital plate of $\$$. (Holotype).

Fig. 33. Panorpa statura n. sp., subgenital plate of ㅇ. (Holotype). Fig. 34. Panorpa statura n. sp., internal skeleton of $q$. (Holotype). Fig. 35. Neopanorpa heii n. sp., subgenital plate of ${ }^{\circ}$. (Allotype). Fig. 36. Neopanorpa heii n. sp., internal skeleton of ?. (Allotype). Fig. 37. Panorpa pusilla n. sp., subgenital plate of . . (Holotype). Fig. 38. Panorpa pusilla n. sp., internal skeleton of $\%$. (Holotype). Fig. 39. Neopanorpa latipennis n. sp., subgenital plate of + . (Holotype). Fig. 40. Neopanorpa latipennis n. sp., internal skeleton of $\$$. (Holotype).

Fig. 41. Neopanorpa varia n. sp., subgenital plate of ㅇ․ (Holotype). Fig. 42. Neopanorpa varia $n$. sp., internal skeleton of $q$. (Holotype). 


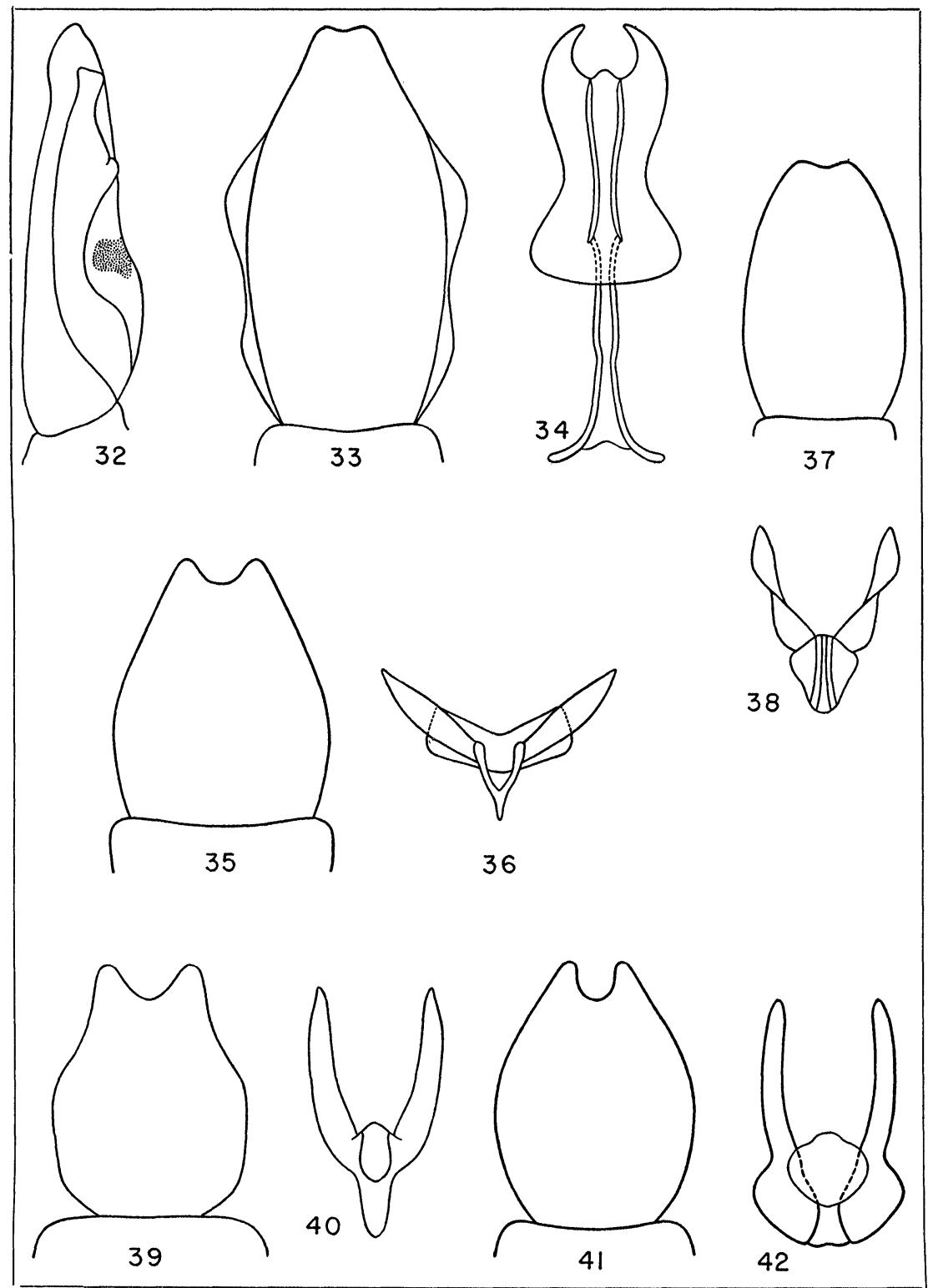

Cheng-Mecoptera 


\section{Explanation of Plate 11}

Fig. 43. Neopanorpa choui $n$. sp., ventral view of $\hat{o}$ genital bulb. (Holotype).

Fig. 44. Neopanorpa choui n. sp., preëpiproct of $\hat{s}$. (Holotype).

Fig. 45. Neopanorpa choui n. sp., ventral view of genital bulb, showing ædeagus. (Holotype).

Fig. 46. Neopanorpa validipennis n. sp., ventral view of $\hat{\delta}$ genital bulb, (Holotype).

Fig. 47. Neopanorpa validipennis n. sp., preëpiproct of $\hat{o} \cdot$ (Holotype).

Fig. 48. Neopanorpa validipennis $\mathrm{n}$. sp., ventral view of $\hat{\delta}$ genital bulb, showing ædeagus. (Holotype).

Fig. 49. Neopanorpa heii n. sp., ventral view of to genital bulb. (Holotype).

Fig. 50. Neopanorpa heii n. sp., preëpiproct of $\hat{s}$. (Holotype).

Fig. 51. Neopanorpa heii $\mathrm{n}$. sp., ventral view of $\hat{o}$ genital bulb, showing ædeagus. (Holotype). 


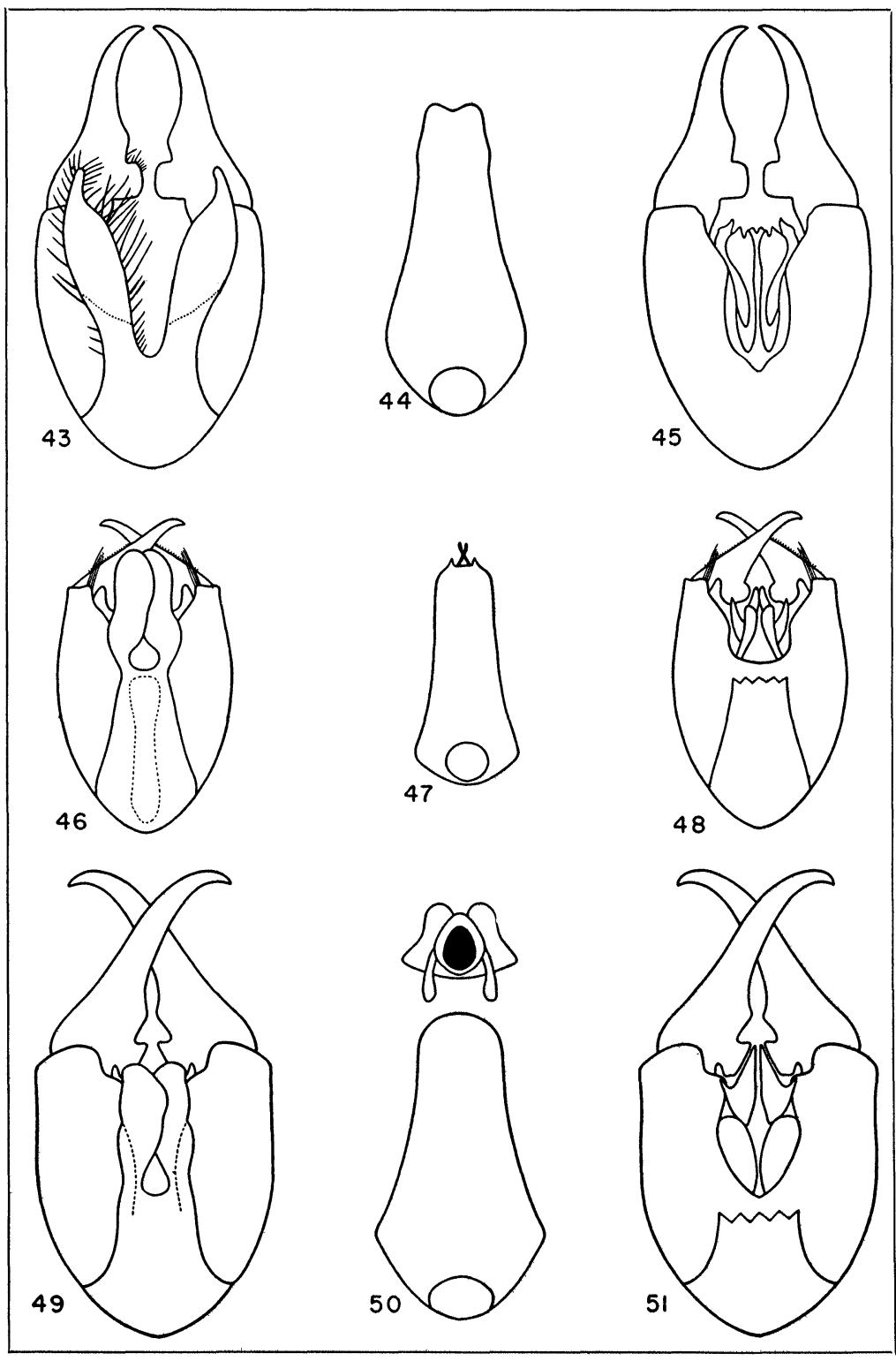

Cheng-Mecoptera 
Fig. 52. Panorpa pusilla n. sp., fore wing of $\$$. (Holotype).

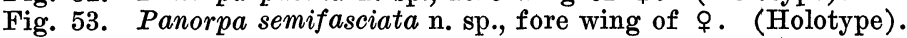

Fig. 54. Panorpa leei n. sp., fore wing of ㅇ. (Holotype).

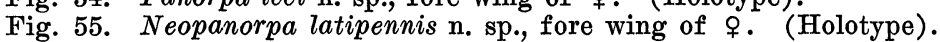
Fig. 56. Neopanorpa varia n. sp., fore wing of $q$. (Holotype).

Fig. 57. Panorpa statura n. sp., fore wing of $q$. (Holotype). 


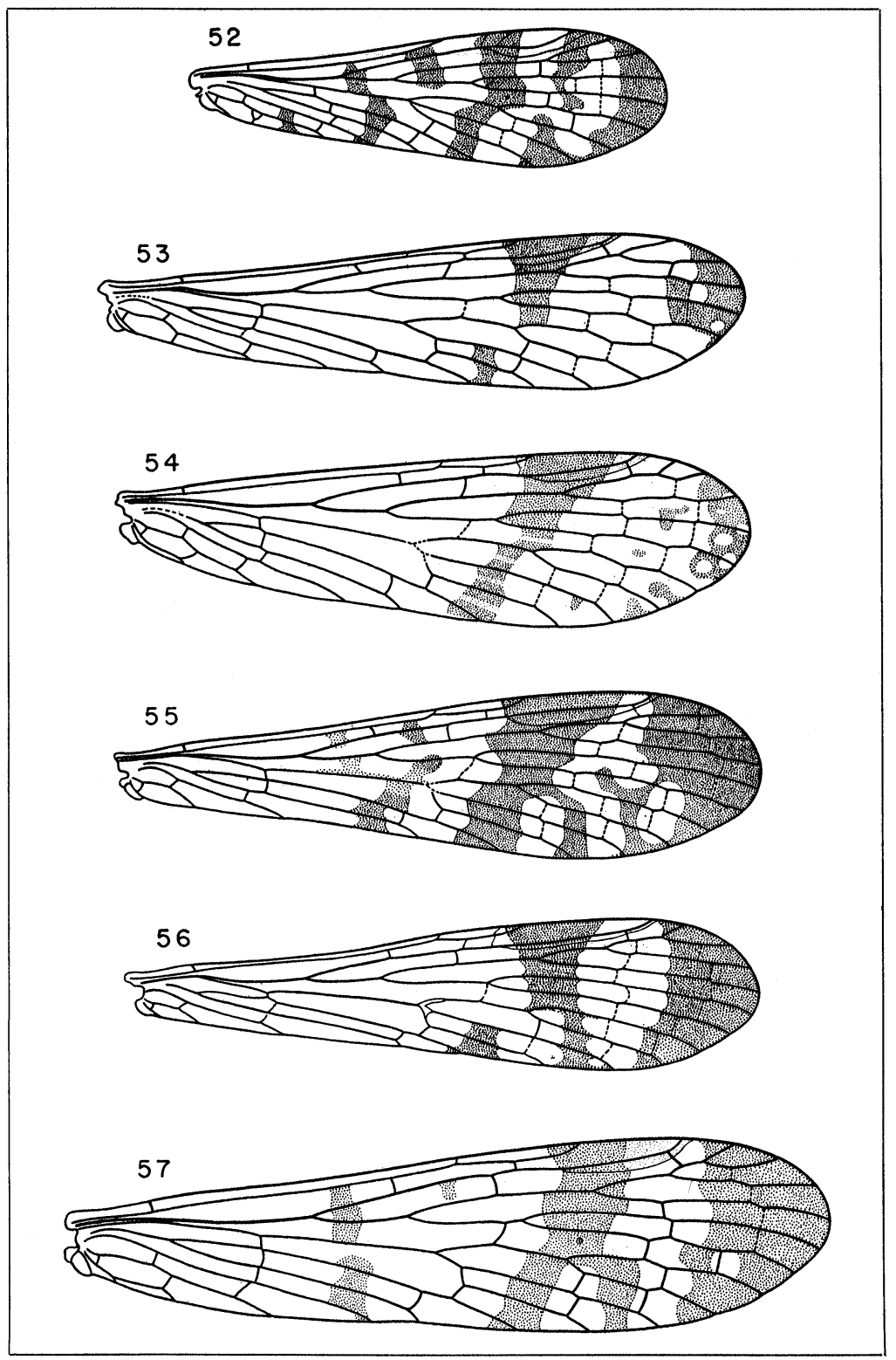

Cheng-Mecoptera 


\section{Explanation of Plate 13}

Fig. 58. Neopanorpa taoi n. sp., preëpiproct of $\hat{\delta}$. (Holotype).

Fig. 59. Bittacus planus n. sp., wings of $\hat{\delta}$. (Holotype).

Fig. 60. Bittacus planus n. sp., terminal abdominal appendages, lateral view of the proctiger. (Holotype).

Fig. 61. Bittacus planus n. sp., terminal abdominal appendages, dorsal view. (Holotype).

Fig. 62. Neopanorpa choui n. sp., lateral view of $\hat{o}$ abdominal segments, showing long median process. (Holotype).

Fig. 63. Bittacus planus n. sp., terminal abdominal appendages, caudal view. (Holotype).

Fig. 64. Neopanorpa validipennis n. sp., dorsal view of the median process of $\hat{o}$. (Holotype).

Fig. 65. Neopanorpa validipennis $\mathbf{n}$. sp., lateral view of the median process of $\hat{o}$. (Holotype).

Fig. 66. Neopanorpa taoi $\mathrm{n}$. sp., ventral view of $\hat{o}$ genital bulb, showing ædeagus. (Holotype).

Fig. 67. Bittacus planus $\mathrm{n}$. sp., terminal of abdominal appendages, lateral view. (Holotype).

Fig. 68. Neopanorpa tao $i$ n. sp., lateral view of abdominal segments of $\hat{o}$. (Holotype). 


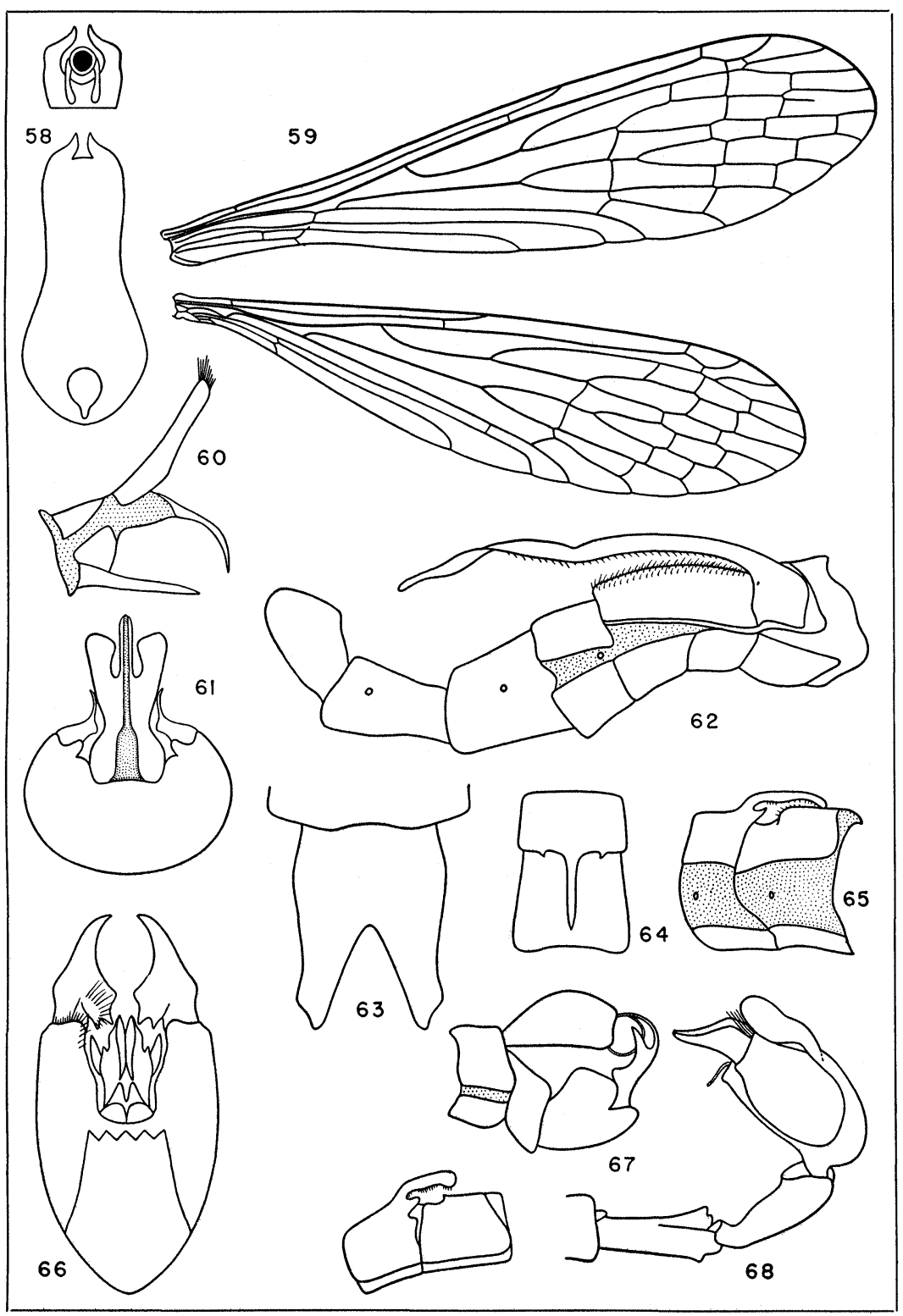

Chena-Mecoptera 

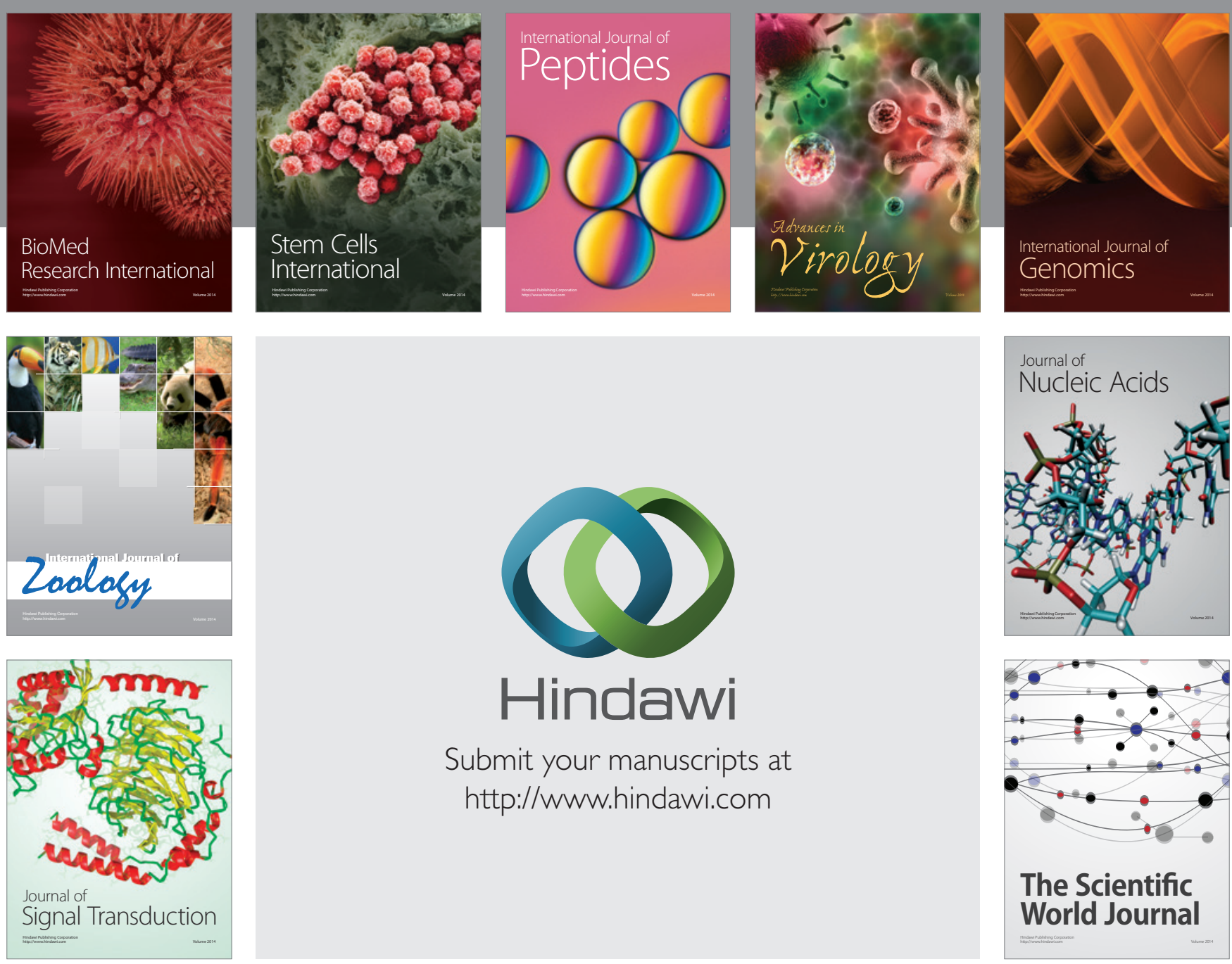

Submit your manuscripts at

http://www.hindawi.com
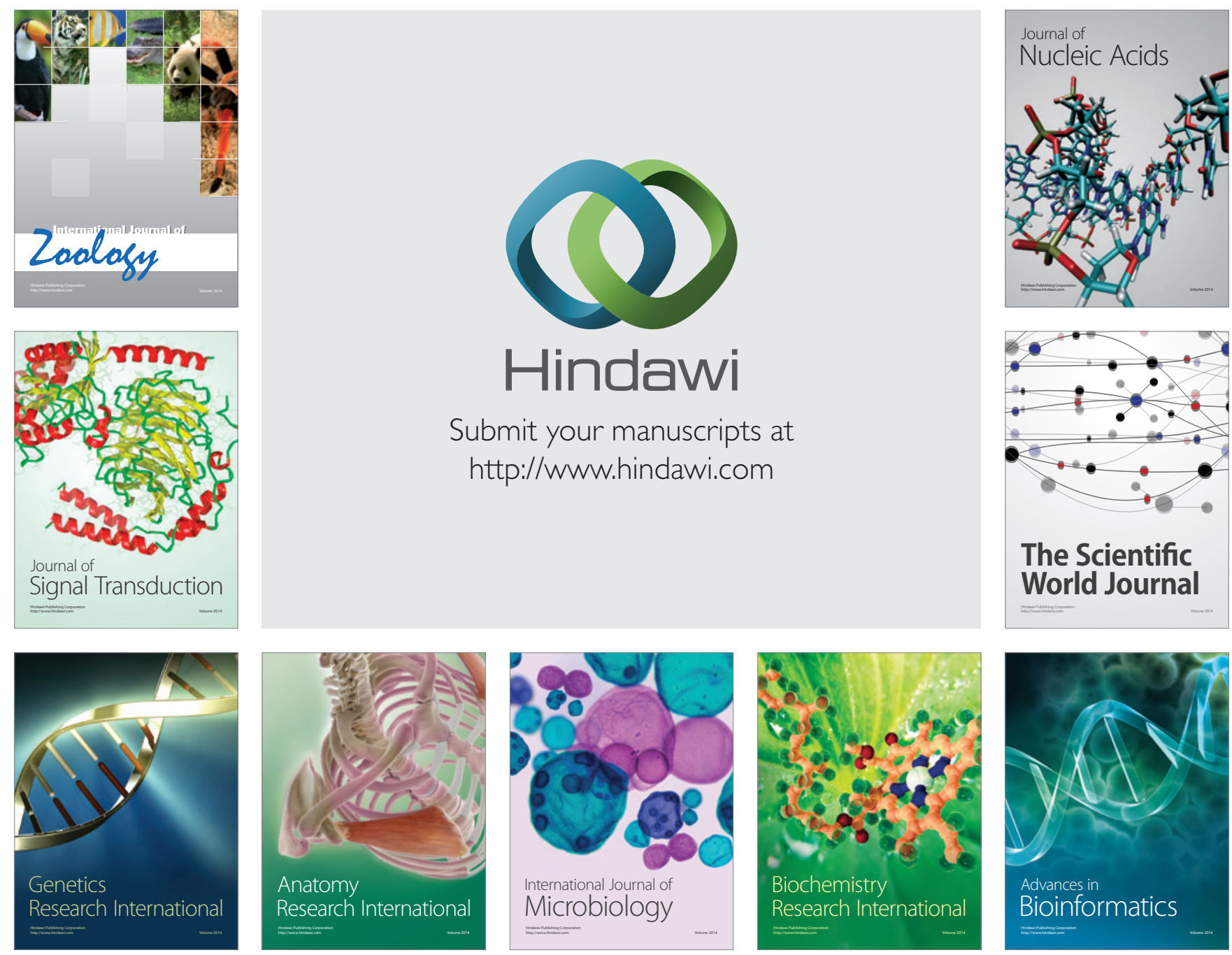

The Scientific World Journal
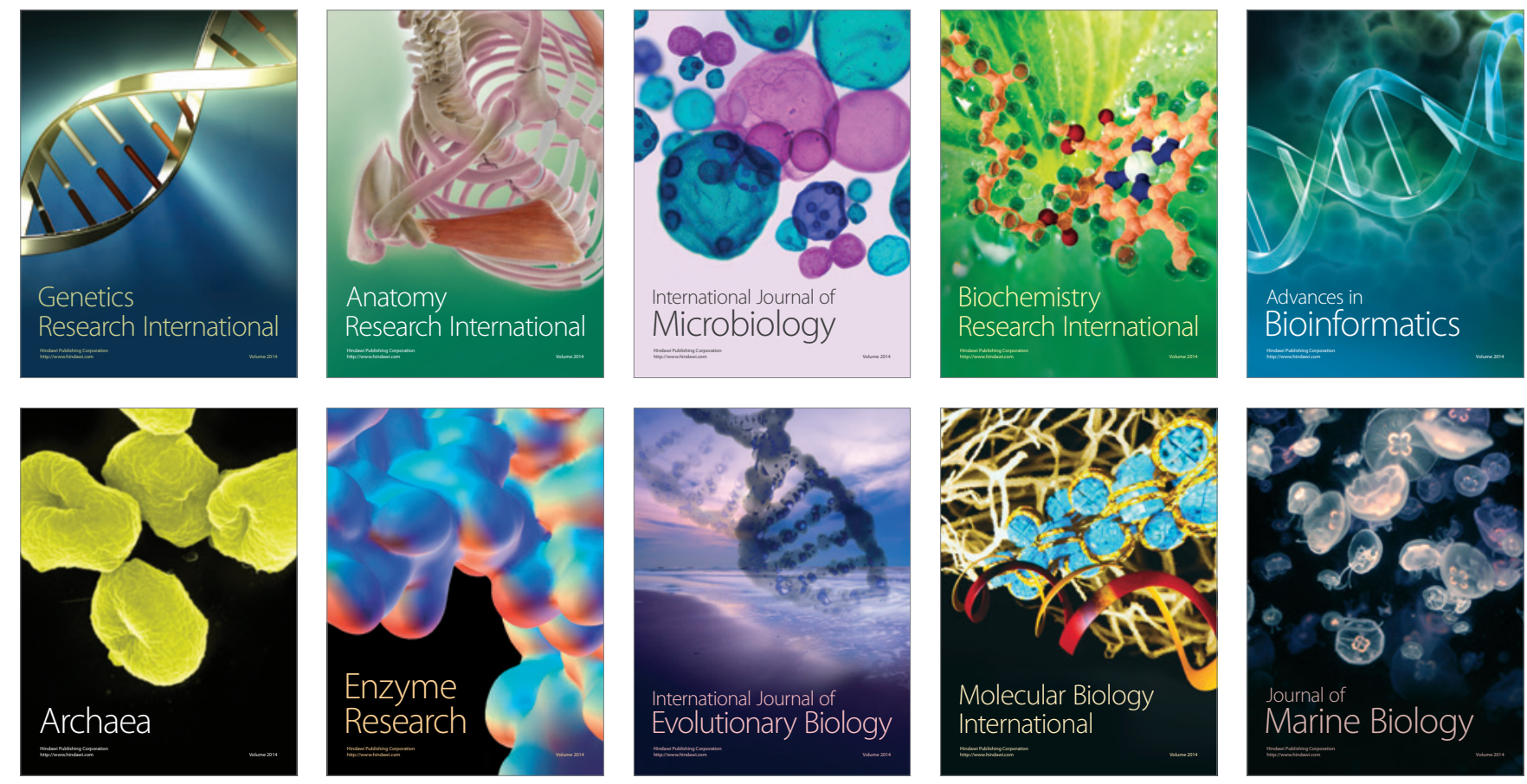